\title{
Utilizing GeoGebra in Application of Integral Module for High School Students
}

\author{
Suci Yuniarti, Tri Hariyati Nur Indah Sari, Husnul Khotimah \\ Department of Mathematics Education, Faculty of Teacher Training and Education, Balikpapan University, Indonesia \\ suci.yuniarti@uniba-bpn.ac.id, tri.hariyati.nis@uniba-bpn.ac.id, husnul.khotimah@uniba-bpn.ac.id
}

\begin{abstract}
The study investigates the practicality of application of integral module supported by GeoGebra to visualize area of plane regions and volume of solids of revolution. This research and development study involves Grade 12 students from four public high schools in Balikpapan, East Borneo, Indonesia. The data obtained from the questionnaire used in the study are analyzed using statistics descriptive. The result shows that application of integral module supported by GeoGebra is practical. The study suggests that utilizing GeoGebra in mathematics learning should be supported by practical learning modules.
\end{abstract}

Keywords-module; application of integral; GeoGebra; high school students

\section{INTRODUCTION}

Today, information and communications technology (ICT) infiltrates classrooms around the world at an exceedingly rapid pace. Teachers face growing challenges as they teach students generation who are digital native and growing up with new technology. In line with the current digital era, teachers are required to integrate ICT in their daily teaching and replace their traditional methods with modern tools and facilities [1]. ICT can be an effective tool in supporting teaching and learning when it is used appropriately [2].

ICT provides productive teaching and learning in order to increase students' creative and intellectual resources [3]. When working with multimedia applications, students are engaged in activities which develop higher order thinking skills such as problem solving, reflecting, recognizing relationship, analyzing and creatively synthesizing information, as they deal with complex and realistic information [4]. These activities will facilitate students to understand the concepts in particular subject, including mathematics.

ICT improves the way mathematics should be taught and enhances student understanding of basic concepts [5]. Students must learn mathematics with understanding, actively building new knowledge from experience and prior knowledge [6]. Understanding has, in effect, become a means and a goal of mathematics education. Furthermore, it seems reasonable to characterize mathematical understanding as a matter of having a world of dynamic mental models that are consistent with the conceptual systems of mathematics [7]. The dynamic nature of mathematical understanding and the corresponding needs for multiple representations serve as a theoretical foundation for the integration of technological tools such as GeoGebra.
GeoGebra is dynamic mathematics software for all levels of education that brings together geometry, algebra, spreadsheets, graphing, statistics and calculus in one easy-to-use package. This free application can be downloaded from www.geogebra.com. Using GeoGebra into everyday teaching and learning is to provide opportunities for students of different mathematical skills and levels for better understanding concepts and fostering them to doing mathematics in new attractive way [8].

Utilizing GeoGebra in mathematics learning should be supported by interactive and practical modules. Modules are printed material about particular topics to provide students to learn independently with limited guidance from the facilitator or teacher. Using modules in mathematics teaching and learning is in line with the change of schools' mathematics curriculum from teacher-centered learning to student-centered learning.

\section{LITERATURE REVIEW}

\section{A. Module}

Module is one of educational materials intended to be used during the processes of teaching and learning. A module is defined as a self-contained, independent unit of a planned series of learning activities designed to help the students accomplish certain well-defined objectives [8]. Learning module is a packet of teaching materials consisting of behavioral objectives, a sequence of learning activities and provisions for evaluations [9]. In this study, module is printed material about particular topics to provide students to learn independently with limited guidance from the facilitator or teacher.

There are some criteria should be fulfilled to make a good and interesting module i.e. self-instructional, self-contained, stand alone, adaptive and user friendly [10]. The module needs to be systematically designed to facilitate learning without the constant supervision of a teacher [11]. In addition, module can be used in nearly any stage of the instructional process including concept introduction and explanation, individual tutorial practice and testing [12].

\section{B. GeoGebra}

GeoGebra was created by Markus Hohenwarter in 2001. GeoGebra is an interactive geometry, algebra, statistics and calculus application, intended for learning and teaching mathematics and science from primary school to university 
level [13]. Furthermore, GeoGebra provides main features like free for noncommercial use; multiplatform; clear and easy understanding graphical user interface; rich database of readymade examples; technical documentation in many languages; marking objects follow the mathematical syntax; ability to save a project in multiple formats; works with LaTeX; all objects in GeoGebra are dynamic; possibility to publish the work on the website through javascript; and program is translated into many foreign languages.

The open-source nature of GeoGebra has important implications both for educators and students. Unlike with commercial products, students are certainly not constrained to use the software only in schools or universities allowed by site licenses, but they can download and install GeoGebra on their private computers. For teachers, GeoGebra offers the powerful opportunity to create interactive online learning environments which has led many teachers to share free materials on the internet [14].

\section{Using GeoGebra to Visualize Area of Plane Regions}

Area of plane regions is one of applications of integral. This topic is learned in Grade 12 for science program. The topic consists of Riemann Sum and application of definite integral to find the area of regions with curved boundary. The capability of GeoGebra to find and visualize area of regions bounded by graphs can be showed as follows.

\section{1) Riemann Sum}

For example, to evaluate the Riemann sum for $f(x)=x^{2}$ on the interval $[-2,2]$ with 8 subintervals, follow these steps:

a) Write " $\mathrm{f}(\mathrm{x})=\mathrm{x}^{\wedge} 2$ " in Input Bar then Enter.

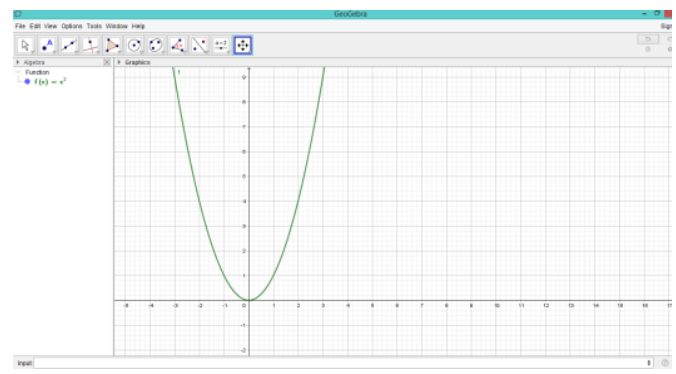

b) Write "LowerSum(f,-2,2,8) in Input Bar then Enter.

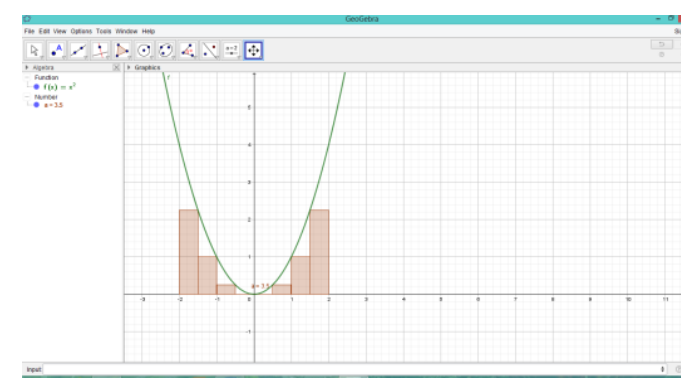

2) Area of Plane Regions

For example, to find the area of region under $f(x)=$ $x^{2}-4$ on the interval $[-2,2]$, follow these steps: a) Write " $\mathrm{f}(\mathrm{x})=\mathrm{x}^{\wedge} 2-4$ " in Input Bar then Enter.

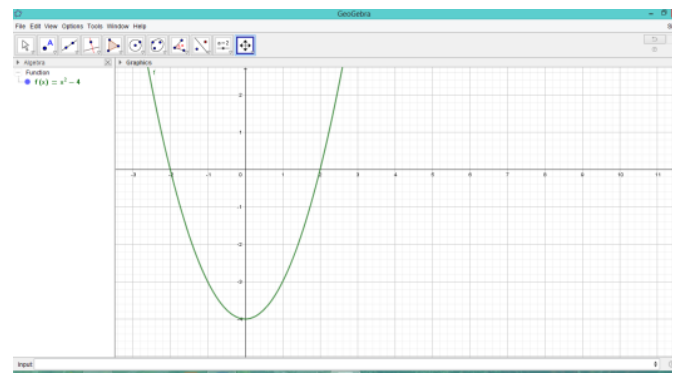

b) Write "Integral (f,-2,2) in Input Bar then Enter.

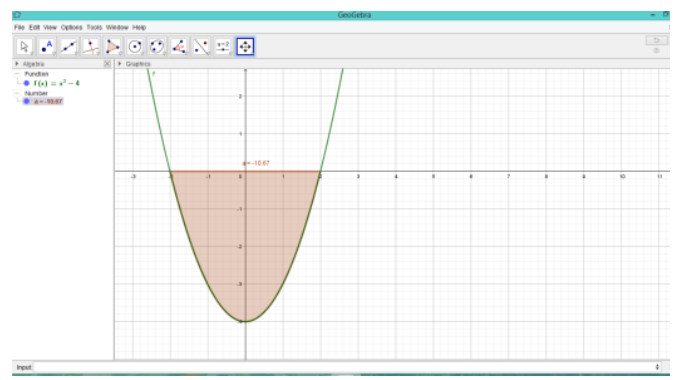

To find the area of region between two curves, for example area of region between $f(x)=x^{2}$ and $g(x)=$ $x+2$, follow these steps:

a) Write " $\mathrm{f}(\mathrm{x})=\mathrm{x} \wedge 2$ " and " $\mathrm{g}(\mathrm{x})=\mathrm{x}+2$ " in Input Bar then Enter.

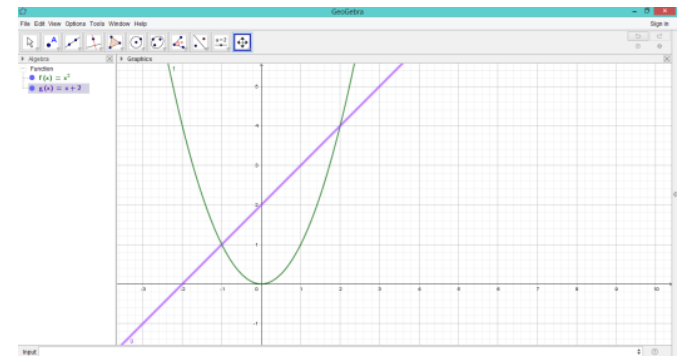

b) Write "Integral Between $(\mathrm{g}, \mathrm{f},-1,2)$ " in Input Bar then Enter.

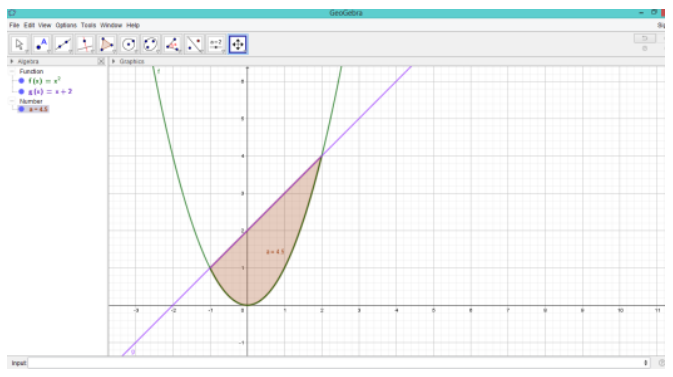

\section{Using GeoGebra to Visualize Volume of Solids of} Revolution

Definite integral also can be used to find the volume of solids of revolution. The solids of revolution can be generated by revolving the region bounded by graph about the $\mathrm{x}$-axis or 
y-axis. The capability of GeoGebra to find and visualize volume of solids of revolution can be showed as follows.

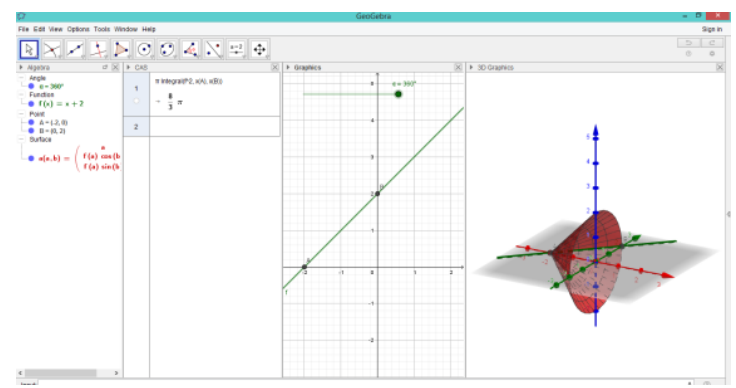

For example, to visualize the volume of solid of revolution generated by revolving the region bounded by $f(x)=x+2$, the $\mathrm{x}$-axis and $\mathrm{y}$-axis about the $\mathrm{x}$-axis, follow these steps:

1) Write " $\mathrm{f}(\mathrm{x})=\mathrm{x}+2$ " in Input Bar then Enter.

2) Open "View" then chose "3D Graphics".

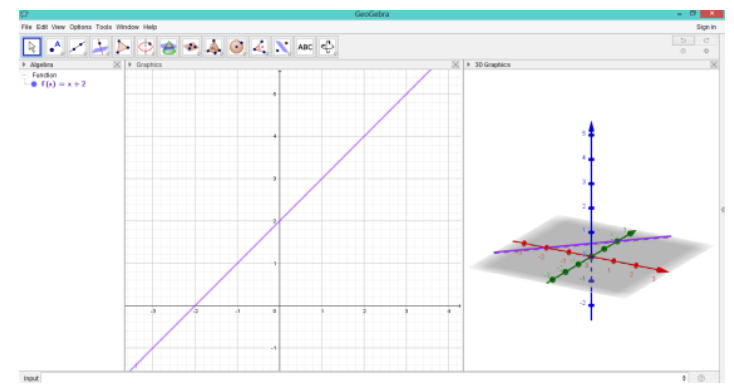

3) Find the intersection between $f(x)$ and x-axis and $f(x)$ and $y$-axis.

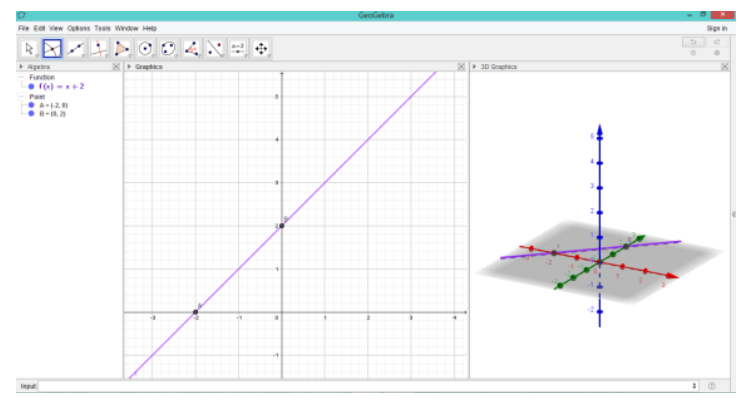

The intersections are point $\mathrm{A}$ and point $\mathrm{B}$.

4) Click "Slider" then chose "Angle".

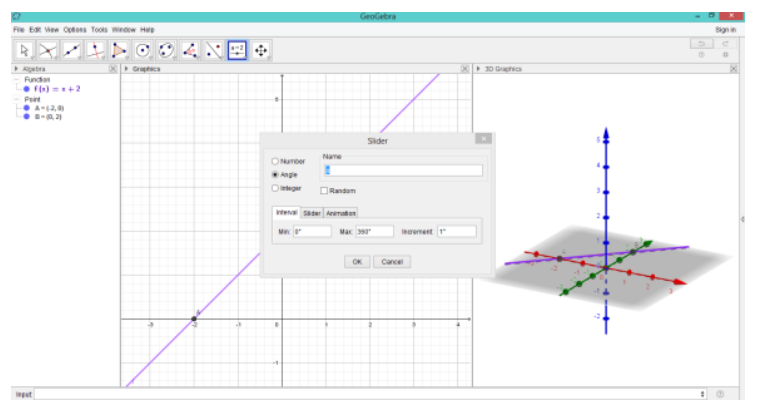

5) Write "Surface(a,f(a)cos(b), $\mathrm{f}(\mathrm{a}) \sin (\mathrm{b}), \mathrm{a}, \mathrm{x}(\mathrm{A}), \mathrm{x}(\mathrm{B})$, b, $0, \alpha)$ " in Input Bar then Enter, Fig. 1.

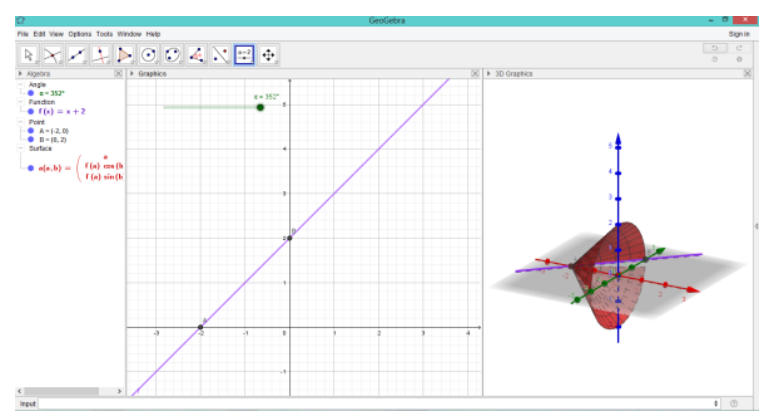

Fig. 1. CAS in GeoGebra

GeoGebra has a simple CAS in the background which has the ability to deal with variables for numbers, vectors and points, find derivatives and integrals of functions [15]. CAS can be used to calculate the volume solids of revolution. From the example above, the volume of solid of revolution generated by revolving the region bounded by $f(x)=x+2$, the $\mathrm{x}$-axis and $y$-axis about the $\mathrm{x}$-axis is $\frac{8}{3} \pi$ volume unit.

\section{METHODOLOGY}

This study is research and development study using 4D model [16]. This model consists of four phases i.e. define, design, develop and dissemination phase. The study only reported the first three phases of the model. In the define phase, the researchers analyzed the gap that exists between the desired outcomes and the existing knowledge and skills of the students. The design phase immediately follows the define phase and information gained from the define phase is translated into a plan for the instructional module including the detailed information about the content to be communicated, the layout and the functionality of the module. In the develop phase, a prototype is developed directly from the design specifications. As a part of this phase, developed materials must be evaluated to ensure they are designed as intended and to verify that instructional content has been properly designed and developed [17].

This research involved Grade XII students from four public high schools in Balikpapan using purposive sampling. One class of Grade XII students was chosen from SMA Negeri 1, SMA Negeri 4, SMA Negeri 6 and SMA Negeri 7 Balikpapan. These three schools were represented high, moderate and low group schools in Balikpapan respectively.

This study employed questionnaire to assess the practicality of application of integral module. The questionnaire was administered by researchers to Grade XII students. The data obtained from the questionnaire was analyzed using descriptive statistics. The module is practical if the mean of the data $(\bar{x})$ is categorized in practical criteria (B). The criteria of practicality can be seen in Table I. 
TABLE I. CRITERIA OF PRACTICALITY

\begin{tabular}{|l|l|l|l|}
\hline \multirow{2}{*}{ No. } & \multicolumn{3}{|l|}{ Criteria of Practicality } \\
\cline { 2 - 4 } & Interval & Category & Criteria \\
\hline 1 & $\bar{x}>16$ & A & Very Practical \\
\hline 2 & $13,33<\bar{x} \leq 16$ & B & Practical \\
\hline 3 & $10,67<\bar{x} \leq 13,33$ & C & Moderately Practical \\
\hline 4 & $13,33<\bar{x} \leq 8$ & D & Slightly Practical \\
\hline 5 & $\bar{x} \leq 8$ & E & Not at all Practical \\
\hline
\end{tabular}

Adapted from Azwar [18]

\section{RESULT AND DISCUSSION}

The result of this study included the result of three phases in 4D model i.e. define, design and develop phase. In the define phase, the researchers analyzed the gap that exists between the desired mathematics learning outcomes and the existing knowledge and skills of the Grade XII students. The result of analysis showed that one of difficult topics in Grade XII is application of integral. In addition, application of integral was taught without application computer support.

The design phase immediately follows the define phase. The information gained from the define phase is translated into a plan for the instructional module including the detailed information about the content, the layout and the functionality of application of integral module. The phase produced prototype application of integral module called Draft I. The Draft I included instructional content about how to solve application of integral problems using GeoGebra.

In the develop phase, Draft I was validated to ensure it is designed as intended and to verify that instructional content has been properly designed and developed. The validation process used expert judgement and involved two experts of calculus and GeoGebra from State University of Yogyakarta and State University of Surabaya. The result of validation showed that Draft I can be used in the study after some revisions is done. The revised Draft I was called Draft II and will be used in the limited tryout to some students. The Draft II included theory of application of integral and instructional content about how to solve application of integral problems using GeoGebra.

The limited tryout of Draft II was held in SMA Negeri 4 Balikpapan. The tryout involved ten students from high, moderate and low group in the class. The students used the module and followed the instructional content written in the module before they filled the questionnaire. The mean of data from the questionnaire is 18.56. Based on Table 1, the mean is categorized A. It means that the result of limited tryout showed that the module was practical. In addition, students also commented that the module is interesting, useful and easy to be understood. The Draft II was revised based on the result of the limited tryout. The revised Draft II was called Draft III and will be used in the field tryout.

The field tryout of Draft III was held in SMA Negeri 1, SMA Negeri 6 and SMA Negeri 7. The students in three schools used the module and followed the instructional content written in the module before they filled the questionnaire. The mean of data from the questionnaire is 17.23. Based on Table 1 , the mean is categorized A. It means that the result of field tryout showed that the module was also practical. In addition, students also commented that the module is good and clear and make them easier to understand the materials, Fig. 2.

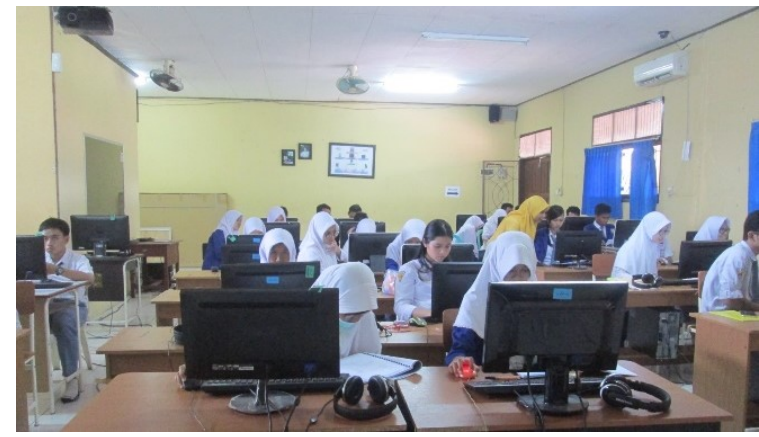

Fig. 2. Field tryout

The result of this study shows that the application of integral module supported by GeoGebra is practical. It means that students can follow the instructional contents to use GeoGebra in the module well. This indicates that utilizing GeoGebra in mathematics learning should be supported by practical module

\section{ACKNOWLEDGMENT}

Thanks to all students who participate in this study and colleagues who support this research until its completions. We would also like to show our gratitude to two validators in this study for evaluating the module before it is used.

\section{REFERENCES}

[1] S. Ghavifekr, A.Z.A. Razak, M.F.A. Ghani, N.Y. Ran, Y. Meixi and Z. Tengyue, "ICT integration in education: Incorporation for teaching and learning improvement," The Malaysian Online J. Educational Technology, vol. 2, pp. 24-45, 2014.

[2] S. Hennessy, D. Harrison and L. Wamakote, "Teacher factors influencing classroom use of ICT in Sub-Saharan Africa," Itupale Online J. African Studies, vol. 2, pp. 39-54, 2010.

[3] S.E. Aduwa-Ogiegbaen and E.O.S. Iyamu, "Using information technology in secondary schools in Nigeria: Problems and prospects." Educational Technology \& Society, vol. 8(1), pp. 104-112, 2005

[4] S. Oyebolu and O. Lemo, "The impact of information and communication technology (ICT) on vocational and technical students' learning," J. Education and Practice, vol. 4(7) 178-183. 2013.

[5] C.C. Keong, S. Horani, and J. Daniel. "A study on the use of ICT in mathematics teaching," Malaysian Online J. Instructional Technology, vol. 2(3), pp. 43-51, 2005

[6] National Council of Teachers of Mathematics, Principles and standards for school mathematics, Reston, VA: NCTM, 2000.

[7] L Bu, J.M. Spector and E.S. Haciomeroglu, "Toward model-centered mathematics learning and instruction using geogebra," in Modelcentered learning: Pathways to mathematical understanding using geogebra, L. Bu and R. Schoen, Eds. Rotterdam: Sense Publishers, 2011, pp $13-40$.

[8] R.M.D. Guido, "Evaluation of a modular teaching approach in materials science and engineering," American J. Educational Research, vol. 2(11), pp. 1126-1130, 2014.

[9] J.W. Robinson, Jr. and W.B. Crittenden, "Learning modules: A concept for extension educators?” J. Extension, pp. 35-44,1972.

[10] Depdiknas, Penulisan Modul. Jakarta: Depdiknas, 2008.

[11] Y. Hashim, "Are instructional design elements being used in module writing?” British J. Educational Technology, vol. 30(4), pp. 341-358, 1999.

[12] J.R. Lux and B.D. Davidson, "Guidelines for the development of computer-based instruction modules for science and engineering," Educational Technology \& Society, vol. 6(4), pp. 125 - 133, 2003. 
[13] D. Majerek, "Application of GeoGebra for teaching mathematics," Advances in Science and Technology Research J., vol. 8(24), pp. 51-54, 2014.

[14] M. Hohenwarter, J. Hohenwarter, Y. Kreis and Z. Lavicza, "Teaching and learning calculus with free dynamic mathematics software GeoGebra," ICME 11, Monterrey, Mexico, 2008.

[15] C. Sangwin, "A brief review of GeoGebra: dynamics mathematics," MSOR Connections, vol. 7(2), pp. 36-38, 2007.
[16] S. Thiagarajan, D. Semmel and M.I. Semmel, Instructional Development for Trainning Teachers of Exceptional Children: A Sourcebook. Minnesota: Central for Innovation on Teaching the Handicaved, 1974.

[17] F. Martin, O.J. Hoskins, R. Brooks and T. Bennett, "Development of an interactive multimedia instructional module," The J. Applied Instructional Design, vol. 3(3), pp. 5-18, 2013.

[18] S. Azwar, Tes Prestasi Fungsi Pengembangan Pengukuran Prestasi Belajar. Yogyakarta: Pustaka Pelajar, 2009. 